\title{
FTIR Method for Peptide Content Estimation and Degradation Kinetic Study of Canarium Nut Protein
}

\author{
Ilma Nugrahani*, Rozana Oktaviary**, Slamet Ibrahim, Tutus Gusdinar, Cintya Apsari
}

Department of Pharmacochemistry, School of Pharmacy, Institut Teknologi Bandung, Bandung, 40132, Indonesia

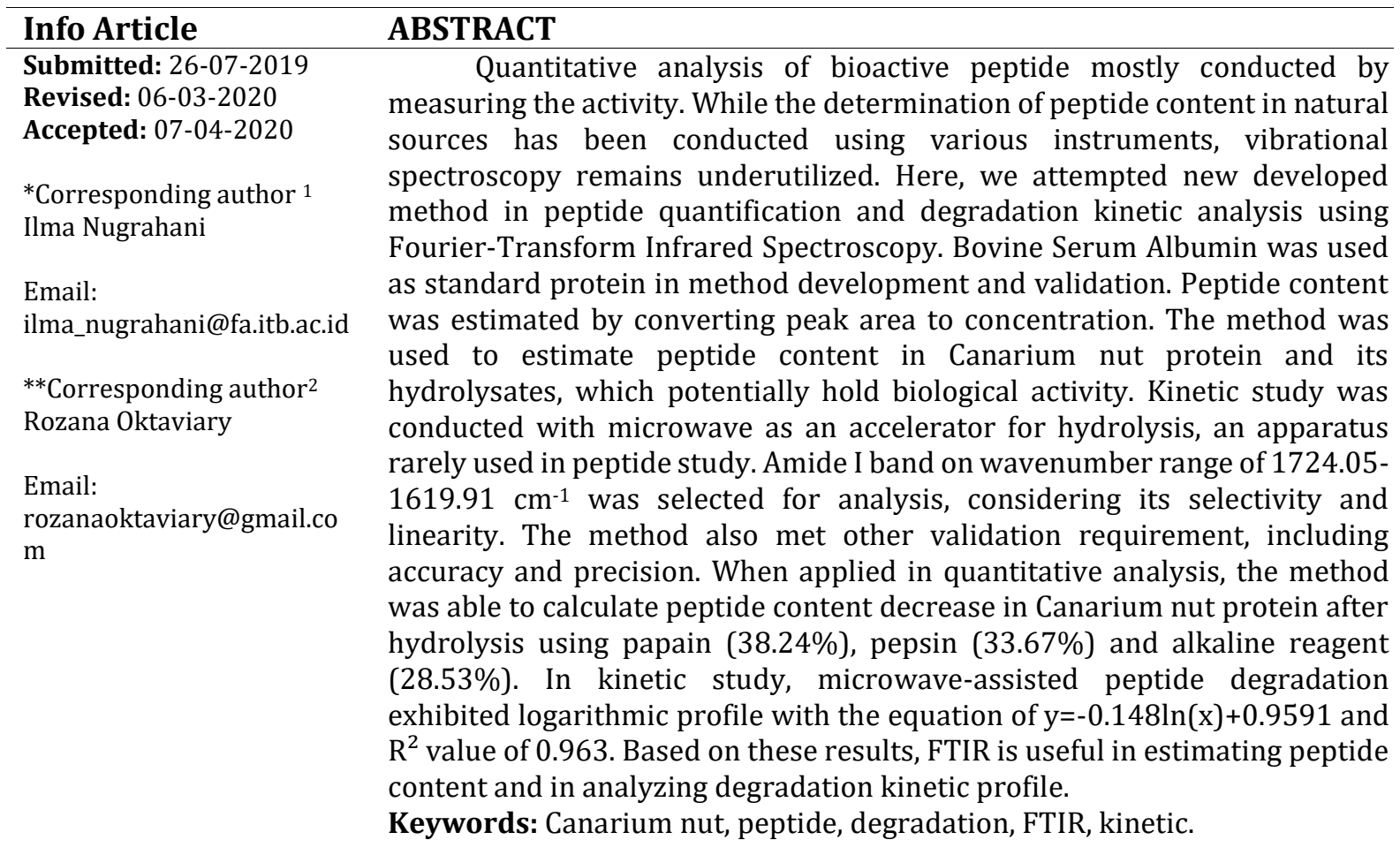

\section{INTRODUCTION}

For many years, natural sources have been an important subject in drug discovery (Subramani and Sipkema, 2019). Indonesia, a biodiverse country endowed with thousand species of flora (Sholikhah, 2016), holds an enormous potential for natural sources-based bioactive compound discovery. Canarium indicum L., also known by the locals as kacang kenari or Canarium nut, is an endemic species of Canarium genus under Bruseraceae family which is grown in eastern part of Indonesia, especially in Maluku (Tamalene et al., 2016). Apart from its utilization as food, nuts were found to also contain bioactive peptide (Wang et al., 2018; Tang, et al., 2012). Bioactive peptides, sometimes termed hydrolysates, are fragments of a protein which are released after hydrolysis (Sanchez and Vazquez, 2017). Reports found that Canarium nut also antioxidant and antiinflammatory activities (Leakey et al., 2008).
Several parameters such as the specificity of hydrolyzing agent, temperature, $\mathrm{pH}$ and time of hydrolysis should be carefully optimized (Chakrabarti et al., 2018; Oshimura and Sakamoto, 2017) to avoid complete degradation of the protein. Sometimes, microwave irradiation is used to accelerate hydrolysis (Kabaha et al., 2011; Zhong et al., 2005). Although the harsh condition may lead to destructive reaction such as oxidation, yielding undesired product (Halldorsdottir et al., 2014).

Currently, most bioactive peptide analysis focused mainly on the measurement of activity. It is well known that biological activity could be directly correlated to the amount of chemical compound. For example, antioxidant activity may be correlated flavonoid and phenolic content in plants (Da Silva and Paiva, 2012; Mello and Quadros, 2014). Instrumental methods such as fluorometry, UV spectrophotometry and high-performance liquid chromatography (HPLC) have been employed 
(Barth, 2007). However, said methods are costly, not environmentally friendly, takes longer time and require great effort (Mallah et al., 2015; Siregar et al., 2018). Fourier transform infrared (FTIR), in comparison, is easier to operate. The instrument enables solid analysis and requires less pretreatment. It has been used widely, especially in qualitative protein analysis for structure elucidation, binding interaction and conformation determination including in post-degradation state (Barth, 2007; Alhazmi, 2019; Vichi et al., 2019). Quantitative analysis using FTIR has also been employed, especially in the field of pharmaceutical science (Bunaciu et al., 2010; Fanelli et al., 2018).

In this study, we aim to develop an innovative FTIR method for peptide content estimation in Canarium nut protein and its hydrolysates, based on absorbance in characteristic region. Furthermore, since the instrument can distinguish between a compound and its resulting product after chemical reaction (Oleszko et al., 2015), we also explore the role of FTIR in microwave-assisted protein degradation kinetic study.

\section{MATERIAL AND METHODS Chemicals}

Canarium nut (Canarium indicum $\mathrm{L}$ ) protein, Bovine Serum Albumin (BSA), Tryptophan (Sigma Aldrich), Tyrosine (Sigma Aldrich), Phenylalanine (Sigma Aldrich), Methionine (Sigma Aldrich), Proline (Sigma Aldrich), Cysteine (Sigma Aldrich), distilled water, Papain (Merck), Pepsin (Merck), $\mathrm{NaOH}$ (Merck), $\mathrm{HCl}$ (Merck), KBr (Merck).

\section{Instruments}

FTIR spectrophotometer (JASCO 4200 Type A, USA), Microwave oven (Samsung R-230R(S), Korea) set at $199.5 \mathrm{Ws}$, analytic scale (Mettler Toledo,USA), pH meter (Mettler Toledo, USA)

\section{Determination of characteristic wavenumber}

Amino acids, BSA and Canarium nut protein in $\mathrm{KBr}(1 \% \mathrm{w} / \mathrm{w})$ pellet was scanned using FTIR spectrophotometer at the range of $4000-400 \mathrm{~cm}^{-1}$. The spectra were examined to determine distinctive band of protein.

\section{Method validation}

The method was validated by evaluating linearity, precision, accuracy, limits of detection and limit of quantification. Linearity test was conducted by measuring peak area of BSA in a series of concentration (1.25-2.5\%) and calculating correlation coefficient of the resulting graph. Accuracy test was conducted by measuring the response of $1.8 \%, 2.0 \%$ and $2.2 \%$ of BSA and calculating percent recovery. Precision was considered by measuring the response of $2.1 \% \mathrm{BSA}$ at 3 different times for 3 days and calculating relative standard deviation (\%RSD). Limit of detection and limit of quantification were calculated from calibration curve as 10S/Slope and 3S/Slope, respectively, where $\mathrm{S}$ is residual standard deviation.

\section{Estimation of peptide content}

For enzymatic hydrolysis, defatted Canarium nut was homogenized in $0.9 \% \mathrm{NaCl}$ to obtain a concentration of $30 \% \mathrm{w} / \mathrm{v}$. Homogenate was filtered and centrifuged at $12.000 \mathrm{rpm}$ for $20 \mathrm{~min}$. The supernatant was adjusted to reach optimum condition for each enzyme (papain: $55^{\circ} \mathrm{C}$, $\mathrm{pH} 7$; pepsin: $37^{\circ} \mathrm{C}, \mathrm{pH} 2$ for pepsin) and was left for $30 \mathrm{~min}$. The enzyme $(1 \% \mathrm{w} / \mathrm{w})$ and supernatant were mixed for $1 \mathrm{~h}$, agitated with magnetic stirrer at $300 \mathrm{rpm}$. Then, enzyme was deactivated by heating at $\pm 100^{\circ} \mathrm{C}$ for $15 \mathrm{~min}$. Hydrolysates were cooled to room temperature and centrifuged $4^{\circ} \mathrm{C}$ at $12.000 \mathrm{rpm}$ for $20 \mathrm{~min}$. The supernatant was collected and freeze-dried.

For alkaline hydrolysis, defatted Canarium nut was mixed with $4 \mathrm{~N} \mathrm{NaOH}$ to obtain a concentration of $30 \%(\mathrm{w} / \mathrm{v})$. Homogenate was filtered and centrifuged at $12.000 \mathrm{rpm}$ for $20 \mathrm{~min}$. Supernatant was placed inside a hydrolysis tube and incubated at $100^{\circ} \mathrm{C}$ for $4 \mathrm{~h}$. Hydrolysate was cooled down in ice bath and neutralized with $6 \mathrm{~N}$ $\mathrm{HCl}$. The hydrolysate was centrifuged at 10.000 rpm for $5 \mathrm{~min}$. The supernatant was collected and dried in the oven at $50^{\circ} \mathrm{C}$ for $1 \mathrm{~h}$. Peptide content was estimated by calculating the peak area of Canarium nut protein, papain, pepsin and alkaline hydrolysates at amide I band.

\section{Reaction kinetic study}

Defatted Canarium nut (100mg) was added with $\mathrm{NaOH} 4 \mathrm{~N}$ dropwise in an evaporating dish and microwaved for $120 \mathrm{~min}$. Samples were taken at $0,1,15,30,60$ and $120 \mathrm{~min}$. The spectrum of each sample (1\%) were scanned and the peak area were calculated. A plot between period and peak area was constructed to determine kinetic profile. 


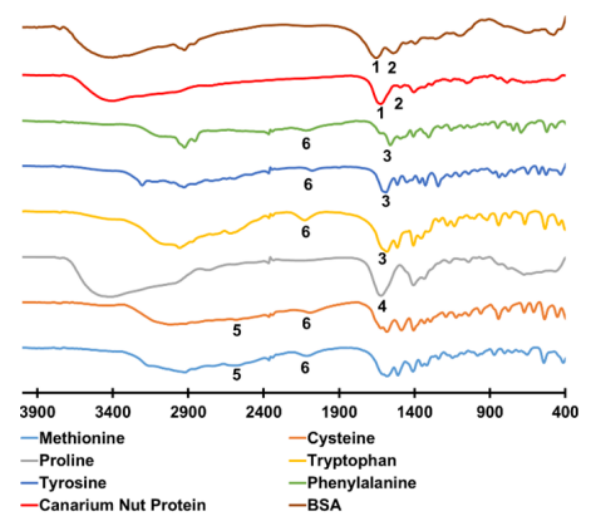

Figure 1. FTIR spectra of amino acids, Canarium nut protein and BSA, with numbers indicating amide I band (1), amide II band (2), C=C aromatic at $1500 \mathrm{~cm}^{-1}$ (3), C=O (4), C-S interaction at $2500 \mathrm{~cm}^{-1}$ (5) and N-H at $\mathrm{NH}^{3+}$ terminal bands (6).
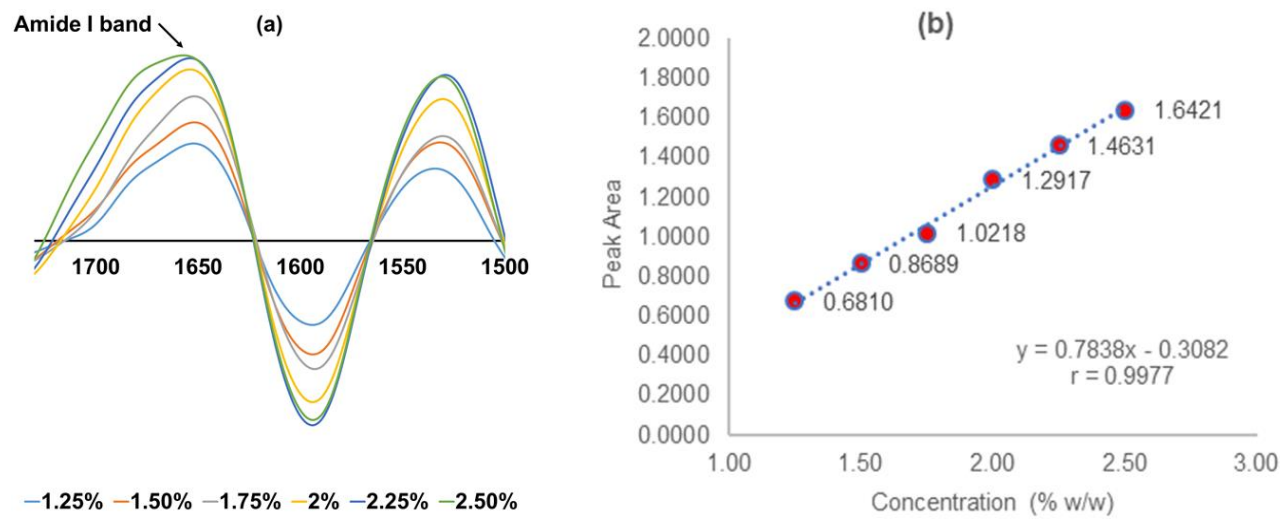

Figure 2. a) Overlaid FTIR spectra of BSA standard in a series of concentration (ranging from 1.25-2.5\%) b) Standard calibration curve of Bovine Serum Albumin (BSA)

\section{RESULT AND DISCUSSION}

\section{Determination of characteristic wavenumber}

Food components such as carbohydrate and fat have characteristic intramolecular bonds. Carbohydrates generates peak around 1200$900 \mathrm{~cm}^{-1}$ indicating $\mathrm{C}-\mathrm{O}-\mathrm{C}$ and $\mathrm{C}-\mathrm{OH}$ stretch while fat generates a peak on around $1700 \mathrm{~cm}^{-1}$ indicating $\mathrm{C}=\mathrm{O}$ strecth in ester linkage (Bagcioglu et al., 2017; Birkel and Rodriguez-Saona, 2011). We observed distinctive peak at $2100 \mathrm{~cm}^{-1}$ generated by amino acids, representing free $-\mathrm{NH}^{3+}$ bond. In protein and proline, the peak disappeared due to bond formation between $-\mathrm{NH}^{3+}$ and - $\mathrm{COO}^{-}$(Leifer and Lippincott, 1957). BSA and Canarium nut protein showed two distinctive peaks, termed amide I (1724.05-1619.91 $\left.\mathrm{cm}^{-1}\right)$, corresponds to $\mathrm{C}=0$ stretch and amide II (1480-1575 $\mathrm{cm}^{-1}$ ), corresponds to the combination between $\mathrm{C}-\mathrm{N}$ stretch and N-H bend (Bagcioglu et al., 2017).
The intensity of amide II band was much lower compared to amide I and overlapped with aromatic $\mathrm{C}=\mathrm{C}$ band (Figure 1 ). Meanwhile, amide I peak appeared strongly in both BSA and Canarium nut protein. Eventhough proline $\mathrm{C}=0$ band $(1600$ $\mathrm{cm}^{-1}$ ) seemed to occupy the same region, Canarium was found to not contain this amino acid (Djarkasi et al., 2017). Marcone et al. (2002) also stated that proline was not detected in Canarium ovatum. Therefore, amide I peak was chosen for peptide content analysis in this research.

\section{Method validation}

Figure 2a showed an overlay of secondary derivative BSA spectra in a series of concentration ranging from $1.25 \%$ to $2.5 \%$. Within this range, linear profile was observed (Figure $2 \mathrm{~b}$ ), generating a correlation coefficient of 0.9977, which is acceptable for linearity test (Peris et al., 2017). 
Table I. Peptide content in Canarium nut protein and its hydrolysates

\begin{tabular}{cccc}
\hline Sample & \% in $\mathbf{K B r}(\mathbf{w} / \mathbf{w})$ & Peak area & Peptide content (\%) \\
\hline Canarium nut protein & 0.4 & 1.2848 & 2.0324 \\
Papain hydrolysate & 0.8 & 0.9102 & 1.5544 \\
Pepsin hydrolysate & 0.8 & 0.7644 & 1.3684 \\
Alkaline hydrolysate & 1 & 0.8281 & 1.4497 \\
\hline
\end{tabular}
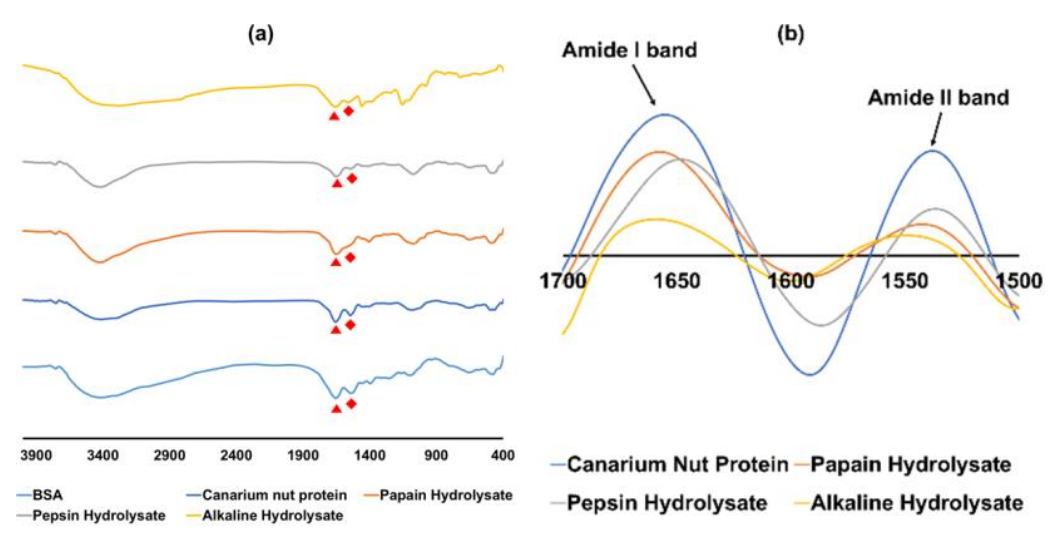

Figure 3. Overlay of a) the spectra of BSA, Canarium nut protein and its hydrolysates (1\% $\mathrm{w} / \mathrm{w}$ in $\mathrm{KBr})$ indicating amide I ( $\mathbf{A})$ and amide II $(\diamond)$, b) second order derivative spectra of Canarium nut protein and its hydrolysates.

A method is considered accurate if the percent recovery is between $80-110 \%$ (Peris et al., 2017). Percent recovery of BSA using this method is between 99.59-100.99\%. The RSD obtained from intra-assay precision test are $1.6882 \%, 1.7686 \%$ and $1.1868 \%$ while intermediate precision test resulted in RSD value of $1.5512 \%$. A method is considered precise if the value of RSD is $\leq 2 \%$ (Peris-Vicente et al., 2017). Therefore, the precision test of this method met the requirement. The LOD and LOQ obtained for this method are $0.12 \% \mathrm{w} / \mathrm{w}$ dan $0.35 \% \mathrm{w} / \mathrm{w}$.

\section{Estimation of peptide content}

FTIR analysis of Canarium nut protein and its hydrolysates shown no notable changes apart from diminishing intensity of amide bands (Figure 3a-b). The absence of $-\mathrm{NH}^{3+}$ band in all hydrolysates indicated that hydrolysis yield peptide instead of amino acid. Amide II band intensity decreased more greatly due to the cleavage of $\mathrm{C}-\mathrm{N}$ bond (Figure $3 \mathrm{~b}$ ). Meanwhile, $\mathrm{C}=\mathrm{O}$ bond did not break, but the intensity of amide I band decreased due to the influence of $\mathrm{C}-\mathrm{N}$ bond loss (Barth, 2007).

Peak area of $1 \% \mathrm{w} / \mathrm{w}$ of Canarium nut protein and its hydrolysates exhibited greater value compared to BSA in the same concentration
(Table I). The presence of asparagine and glutamine, which areabundant in food, may increase the intensity of amide I and amide II bands due to the overlap between intra- and intermolecular amide bond (Barth, 2007). Peptide content in papain and pepsin hydrolysates decreased and left only $38.24 \%$ and $33.67 \%$ of the initial concentration while alkaline hydrolysate left only $28.53 \%$. This result confirmed that nonselective reagent was slightly more efficient compared to enzymes in cleaving peptide bonds.

\section{Reaction kinetic study}

As previously mentioned, FTIR enables qualitative and quantitative analysis in stability study. In this research, the method was employed to study microwave assisted protein degradation. Microwave could accelerate hydrolysis reaction to yield peptide fragment (Quitain et al., 2006). However, in the presence of alkali and oxidants, along with high temperature generated from the irradiation, degradation occurs (Fan et al., 2016). Canarium nut protein turned brownish due to oxidation after microwaving, thus confirmed this theory.

Peptide content (represented by amide I peak area) declined steeply in the first $30 \mathrm{~min}$ and continue to decrease in slower rate. 
The reaction exhibited negative logarithmic profile (Figure 4) which indicates decreasing rate over time. An equation of $y=-0.148 \ln (x)+0.9591$ were constructed with the value of $R^{2}=0.963$. From this result, we expect complete degradation after 600-700 minutes of microwaving.

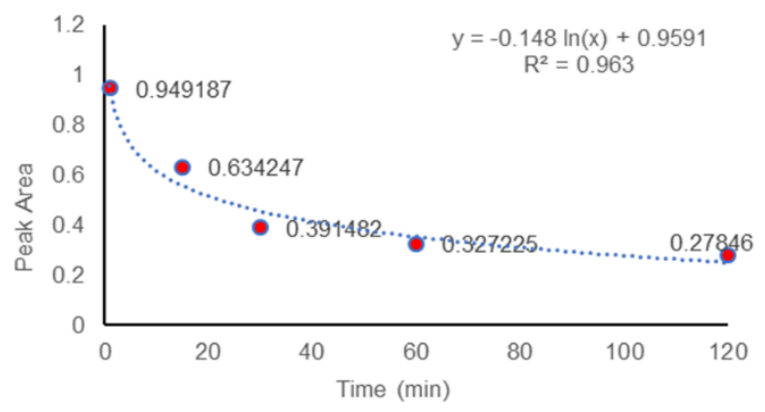

Figure 4. Kinetic profile of microwave-assisted degradation of Canarium nut protein

Protein hydrolysis kinetic studies have been reported (Motyan, 2013 and Warner, 1942). However, the utilization of FTIR in the construction of reaction profile is scarce. Currently, vibrational spectroscopy has been used for qualitative analysis to observe changes in protein structure after degradation (Barth, 2007; Vichi et al., 2019). Meanwhile, in this research, we obtained more information regarding protein degradation, such as reaction profile and optimum period for complete reaction.

\section{CONCLUSION}

FTIR as rapid method for estimation of peptide content was successfully developed and validated. In addition, ompared to bioactive assay and other instrumental analysis such as liquid chromatography, FTIR is simpler, easier to operate, requires little to no pretreatment and more environmentally friendly due to the absence of solvent usage. The method was applied in quantitative analysis of Canarium nut protein as well as its hydrolysates and found useful to determine the efficiency of each hydrolyzing agent. From degradation kinetic study, we generated a profile which could predict the end point for microwave-assisted alkaline hydrolysis of protein.

\section{ACKNOWLEDGEMENT}

This work was funded by Magister Research Program, 2019, Directorate of Higher Education, Ministry of Research, Technology and Higher Education of the Republic of Indonesia.

\section{REFERENCES}

Subramani R., Sipkema D., 2019. Marine Rare Actinomycetes: A Promising Source of Structurally Diverse and Unique Novel Natural Products. Mar. Drugs. DOI. $10.3390 /$ md17050249.

Sholikhah EN., 2016 Indonesian Medicinal Plants as Sources of Secondary Metabolites for Pharmaceutical Industry. J. Med. Sci. DOI. 10.19106/JMedSci004804201606.

Tamalene MN., Al Mudhdhar MHI., Suarsini E., Rahman F., Hasan S., 2016. Ethnobotany of Canarium plant species used by Tobelo Dalam (Togutil) ethnic community of Halmahera Island, Indonesia. Biodiversitas. DOI. 10.13057/biodiv/d170109.

Sanchez A., Vazquez A., 2017. Bioactive peptide: A review. Food Qual. Saf. DOI. 10.1093/fqsafe/fyx006.

Tang L., Sun J., Zhang HC., Zhang CS., Yu LN., Bi J., Zhu F., Liu SF. Yang QL., 2012. Evaluation of Physicochemical and Antioxidant Properties of Peanut Protein Hydrolysate. PLoS One. DOI. 10.1371/journal.pone.0037863.

Wang C., Tu M., Wu D., Chen H., Chen C., Wang Z., Jiang L., 2018. Identification of an ACEInhibitory Peptide from Walnut Protein and Its Evaluation of the Inhibitory Mechanism. Int. J. Mol. Sci. DOI. 10.3390/ijms19041156.

Leakey R, Fuller S., Treloar T., Stevenson L., Hunter D., Nevenim T., Binifa J., Moxon J., 2008. Characterization of tree-to-tree variation in morphological. nutritional and medicinal properties of Canarium indicum nuts. Agrofor. Syst. DOI. 10.1007/s10457-0079103-4.

Chakrabarti S., Guha S., Majumder K., 2018. FoodDerived Bioactive Peptides in Human Health: Challenges and Opportunities. Nutrients. DOI. 10.3390/nu10111738.

Oshimura E., Sakamoto K., 2017. Amino Acids, Peptides, and Proteins, in: Cosmetic Science and Technology, Elsevier, Netherlands. pp. 285-303.

Kabaha K., Taralp A., Cakmak I., Ozturk L., 2011. Accelerated Hydrolysis Method to Estimate the Amino Acid Content of Wheat (Triticum durum Desf.) Flour Using Microwave Irradiation. J. Agric. Food Chem. DOI. 10.1021/jf103678c

Zhong H., Marcus SL., Li L., 2005. Microwaveassisted acid hydrolysis of proteins combined with liquid chromatography MALDI MS/MS for protein identification. J. 
Am. Soc. Mass Spectrom. DOI. 10.1016/j.jasms.2004.12.017.

Halldorsdottir SM., Sveinsdottir H., Freysdottir J., Kristinsson HG., 2014. Oxidative processes during enzymatic hydrolysis of cod protein and their influence on antioxidant and immunomodulating ability. Food Chem. DOI. 10.1016/j.foodchem.2013.07.053.

Da Silva MC., Paiva SR., 2012. Antioxidant activity and flavonoid content of Clusia fluminensis Planch. \& Triana. An. Acad. Bras. Ciênc. DOI. 10.1590/S0001-37652012000300004

Mello LD., Quadros GP., 2014. Correlation between antioxidant activity and total phenolic content with physicochemical parameters of blended extracts of Camellia sinensis. Acta Sci. Health Sci. DOI. 10.4025/actascihealthsci.v36i1.12615.

Barth A., 2007. Infrared Spectroscopy of Proteins. Biochim. Biophys. Acta. DOI. 10.1016/j.bbabio.2007.06.004.

Mallah MA., Sherazi ST., Bhanger MI., Mahesar SA., Bajeer MA., 2015. A rapid Fourier-transform infrared (FTIR) spectroscopic method for direct quantification of paracetamol content in solid pharmaceutical formulations. Spectrochim. Acta A Mol. Biomol. Spectrosc. DOI. 10.1016/j.saa.2015.01.036.

Siregar C., Martono S., Rohman A., 2018. Application of Fourier transform infrared (FTIR) spectroscopy coupled with multivariate calibration for quantitative analysis of curcuminoid in tablet dosage form. J. Appl. Pharm. Sci. DOI. 10.7324/JAPS.2018.8821

Alhazmi HA., 2019. FT-IR Spectroscopy for the Identification of Binding Sites and Measurements of the Binding Interactions of Important Metal Ions with Bovine Serum Albumin. Sci. Pharm. DOI. 10.3390/scipharm87010005.

Vichi A., Eliazyan G.m Kazarian SG., 2018. Study of the Degradation and Conservation of Historical Leather Book Covers with Macro Attenuated Total Reflection-Fourier Transform Infrared Spectroscopic Imaging. ACS Omega. DOI. 10.1021/acsomega.8b00773.

Fanelli S., Zimmermann A., Totoli EG., Salgado HRN., 2018. FTIR Spectrophotometry as a Green Tool for Quantitative Analysis of Drugs: Practical Application to Amoxicillin. J. Chem. DOI. 10.1155/2018/3920810.
Bunaciu AA., Aboul-Enein HY., Fleschin S., 2010. Application of Fourier Transform Infrared Spectrophotometry in Pharmaceutical Drugs Analysis. Appl. Spectrosc. Rev. DOI. 10.1080/05704928.2011.565532.

Bagcioglu M., Zimmerman B., Kohler A. 2017. A Multiscale Vibrational Spectroscopic Approach for Identification and Biochemical Characterization of Pollen. PLoS One. DOI. 10.1371/journal.pone.0137899.

Birkel E., Rodriguez-Saona L., 2011. Application of a Portable Handheld Infrared Spectrometer for Quantitation of trans Fat in Edible Oils. J. Am. Oil Chem'. Soc. DOI. 10.1007/s11746011-1814-z.

Leifer A., Lippincott ER., 1957. The Infrared Spectra of Some Amino Acids. J. Am. Chem. Soc. DOI. 10.1021/ja01576a006.

Djarkasi DSS., Lalujan L., Nurali EJN., Tuju TJD., Rawung D., Sumual MF., 2017. Chemical Composition and Antioxidant Properties of Kenari (Canarium indicum) Nut. Pharm. Chem. J. tpcj.org/chemical-composition-andantioxidant-properties-of-kenari-canariumindicum-nut

Marcone MR., Kakuda Y., Jahaniaval F., Yada RY., Montevirgen LS., 2002. Characterization of the proteins of Pili nut (Canarium ovatum, Engl.). Plant Foods Hum. Nutr. DOI. 10.1023/a:1015266423254

Peris VJ., Esteve-Romero J., Carda-Broch S., 2015. Validation of Analytical Methods Based on Chromatographic Techniques: An Overview, in: Analytical Separation Science, edited by Anderson J., Alain B., Veronixa P., Apryll S., Wiley-VCH, Weinheim. pp. 1757-1808.

Quitain AT., Daimon H., Fujie K., Katoh S., Moriyoshi T., 2006. Microwave-Assisted Hydrothermal Degradation of Silk Protein to Amino Acids. Ind. Eng. Chem. Res. DOI. 10.1021/ie0580699.

Fan D., Hu B., Lin L., Huang L., Wang M., Zhao J., Zhang H., 2016. Rice protein radicals: growth and stability under microwave treatment. RSC Adv. DOI. 10.1039/c6ra15402f.

Motyan JA., Toth F., Tozser J., 2013. Research applications of proteolytic enzymes in molecular biology. Biomolecules. DOI. 10.3390/biom3040923.

Warner RC., 1942. The Alkaline Hydrolysis of Egg Albumin. J. Biol. Chem. DOI. 10.3746/pnf.2015.20.3.183. 